\title{
ROLE OF UDUMBARADI TAIL IN THE MANAGEMENT OF VAGINAL DISCHARGE DUE TO CERVICAL EROSION: A CASE REPORT Chaurasia Ranju Kumari ${ }^{1}$, Bhati Kuldeep Singh ${ }^{2}$ \\ ${ }^{1}$ PG Scholar, Dept. of Prasuti-Stree Roga, National Institute of Ayurveda, Jaipur, Rajasthan, India ${ }^{2}$ PG Scholar, Dept. of Shalya Tantra, National Institute of Ayurveda, Jaipur, Rajasthan, India
}

Received on: 03/05/13 Revised on: 10/06/13 Accepted on: 19/07/13

\author{
*Corresponding author \\ E-mail: ranju.chaurasia@gmail.com \\ DOI: $10.7897 / 2277-4343.04438$ \\ Published by Moksha Publishing House. Website www.mokshaph.com \\ All rights reserved.
}

\begin{abstract}
Cervical erosion is a common gynecological disorder. This benign lesion is sometime much troublesome due its chronicity and nature of recurrence. It is a condition where the squamous epithelium of the ectocervix is replaced by columnar epithelium which is continuous with the endocervix. Excessive vaginal discharge is the most common findings of the cervical erosion may be due to the overgrown or overactive cervical crypts. It is more near to the Karnini Yonivyapada in Ayurveda according to the treatment and some of the clinical features. The principle of treatment of Ayurveda is comparable to that of modern system of medicine in which cryosurgery and diathermy are used to destruct the columnar epithelium and facilitate the growth of new healthy stratified squamous epithelium. But because of various side effect like excessive mucoid discharge per vagina for a long time, sometimes cervical stenosis, accidental burns, bleeding and recurrence of the disease may happen. Hence the Ayurvedic management seems to be more practical, effective, not costly, non surgical and have negligible side effects. Due to serious consequences of the disease it becomes necessary to pay immediate attention towards this most troublesome disease of female. In chronic stage it can shows malignant changes. This present case study was carried out in OPD of Prasuti-Stree Roga Department, National Institute of Ayurveda, Jaipur, Rajasthan, India and the treatment drug i.e. Udumbaradi tail (Charaka Chikitsa 30/73-76) was taken. This drug has shown marked improvement in relieving all the symptoms of cervical erosion and was seen more effective in decreasing the vaginal discharge.
\end{abstract}

Keyword: Cervix, Erosion, Benign, Karnini.

\section{INTRODUCTION}

Cervical erosion is also known as cervical ectopy. It is a benign lesion and is the commonest gynecological condition seen in the OPD's. It is commonest finding on routine pelvic examination during the fertile age group. It is not a fatal condition. The squamous covering of the vaginal aspect of the cervix is replaced by columnar epithelium, which is usually continuous with that lining the endo-cervix ${ }^{1}$. It is not an ulcer or the area denuded of epithelium ${ }^{2}$. Appearance of erosion is bright red because of underlying vascularity. It is not a static condition. The demarcation line between the two epithelium moves to and from the external os. It is said to be healed when the erosion advancing towards the os. During this process the obstruction of ducts takes place and produce nabothian cysts. The columnar epithelium is less resistant to infection than squamous epithelium. No direct reference regarding the Karnini Yonivyapad is present in the text which make it's resemblance with cervical erosion. The etiopathogenesis, clinical feature and principle of treatment are similar to cervical erosion ${ }^{3}$. Symptoms of cervical erosion i.e. discharge and erosion (like in Karnika) and the treatment mentioned in the Ayurvedic texts, it can be correlated with the Karnini Yonivyapad. On the basis of the etiology we can conclude that Karnini is chiefly the disease of reproductive age group (Charak Samhita Chikitsa 30/27, 28) ${ }^{4}$, and is more commonly seen in sexually active female. Nidana sevan vitiates the vata (apana vayu). Kha-vaigunya is present in the artavaha strotas, so here the vitiated vata get mixed with kapha dosha and rakta dhatu and in this way the dosha dushya sammurchana is completed. Adhisthana of disease is the garbhashaya dwara mukha i.e. cervix (Astanga Samgraha Uttartantra 38/59 indu tika), so in the stage of vyakta avashtha, Karnika is formed here which is the cardinal symptom of Karnini Yonivyapada. About $80 \%$ women suffer from the cervical erosion i.e. benign condition of female genital tract during their life time. In modern system of medicine cryosurgery and diathermy are used to destruct the columnar epithelium and facilitate the growth of new healthy stratified squamous epithelium. Various side effects like excessive mucoid discharge per vagina for a long time, sometimes cervical stenosis, accidental burns, bleeding and recurrence of the disease are associated with this treatment. Hence the Ayurvedic management seems to be more practical, effective, not costly, non surgical and have negligible side effects. Due to serious consequences of the disease it becomes necessary to pay immediate attention towards this most troublesome disease of female.

The Ayurvedic treatment having the properties of lekhana, sodhana ${ }^{5}$, ropana, stambhana, kaphaghna ${ }^{6}$ can effectively cure this disease. All the Acharya have emphasized on the Bahirparimarjan Chikitsa having vata kapha nashak properties cure the disease. So in the present case study Udumbaradi Tail (Charaka Chikitsa 30/73-76) was prepared according to 'Taila Paka Vidhi' mentioned in Sharangdhara Samhita. Paka was done till 5 days (daily for two hours on manda heat) till the samyaka lakshana of madhyama paka were obtained.

\section{Case Report}

A 32year old lady came in May 2012 in the OPD PrasutiStree Roga, NIA, Jaipur, Rajasthan, India with chief 
complaint of excessive watery vaginal discharge from one year, lower abdominal pain and pains all the upper and lower extremities. For this she took treatment from different government allopathic hospital, but got no relief. Then she came to the National Institute of Ayurveda in Prasuti-Stree Roga OPD for better treatment.

\section{On examination}

On per speculum examination, it was found that both the lips of cervix were eroded, thick white discharge present, vaginal wall was normal and oozing of blood on rubbing with gauze piece was present. On bimanual digital examination it was found that uterus was antiverted, antiflex and normal in size and mobility non Ender, cervix was gritty on touch and both the fornixes were normal. In the first visit the case was diagnosed as case of cervical erosion and few investigations were carried out and the reports were as follows

\section{Blood investigations}

$\mathrm{Hb}-11.3 \mathrm{gm} \%$, TLC-8600th/ul, ESR-10mm $/ \mathrm{hr}$, Neutrophill-60\%， Lymphocytes-35\%， Eosinopill-2\%, Monocytes-2\%, Basophill-0\%, RBS- 90.4mg/dl; HIV, HBsAg, VDR-negative.

Ultrasonography for uterus and adnexae - Normal study
Urine for routine and microscopy - Normal

Pap's Smear report - Mild inflammatory

\section{Procedure of Udumbaradi tail application}

After taking written informed consent application of drug was done. Patient was called for Udumbaradi tail application on the third day of clearance of menstrual flow. Patient was kept in lithotomic position and preparation of part was done with savlon solution. The cervix was exposed with Cusco's speculum and cleaned properly. Udumbaradi tail was soaked with a gauze piece and kept in contact with the cervix. The oil was applied over the cervix and a pichu (piece of cotton wrapped with gauze and tie with thread) soaked with tail was kept inside the vagina for 4 to 6 hours. It was kept close to the cervix in such a way that some length of thread remained outside of the vagina. Patient was explained well to remove the pichu by holding this thread. The entire procedure was done for fourteen days for two consecutive cycles. After completion of the treatment patient was called weekly interval to see the symptomatic relief.

Don't: Sexual intercourse during the period of treatment.

\section{Effect of Treatment}

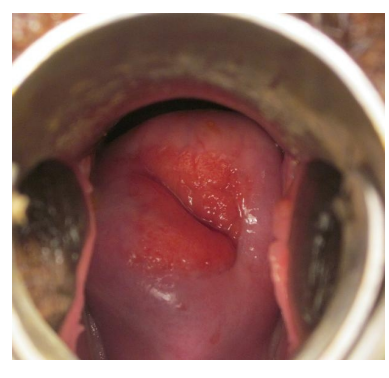

Before treatment

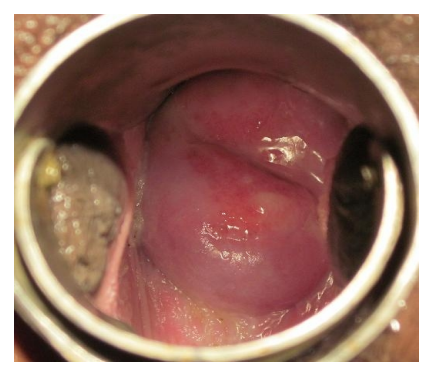

After treatment

Cervix of patient during Cusco's speculum examination

\section{RESULT}

The present drug gave the relief to the symptoms mainly vaginal discharge after first menstrual cycle treatment. Gradually the eroded area also minimizes. The oozing of blood from eroded area after rubbing with gauze piece was also minimized. Maximum improvement was noticed in the vaginal discharge. It was completely abolished.

\section{DISCUSSION}

Cervical erosion is found in the fertile age group i.e. 2035 years, because of the repeated deliveries; there is local trauma in the Cervix, which may produce erosion. Due to hyperplasia of cervical glands various symptoms like vaginal discharge, contact bleeding, back pain, pelvic discomfort etc. produce which are disturbing elements in the daily life style of the woman. Vaginal discharge was disappeared earlier in this case. The use of Udumbaradi tail probably prevents the congestion or hyperemia, thus prevented regeneration of superficial columnar cell. Most of the drug present in Udumbradi tail is having anti- inflammatory, anti-septic and anti-microbial activities which prevent the eroded area from infection and may help in decrease the vaginal secretion. Anti-inflammatory effect of Udumbradi tail may help to minimize the prostaglandin secretion and hence the lower abdominal pain was cured in this case. Describing the effectiveness of this oil Acharya Charak mentions that with the use of this oil the darun yoni will be cured in only seven day or one week $^{7}$. By virtue of shukshama ${ }^{8}$ and vyavayi ${ }^{8}$ properties the drug is easily absorbed through the epithelium and mucosa. Snigdha guna of tila and jaati helps in correction of khavaigunya of artavavaha strotas. The main ingredient in this oil i.e. panchavalka and udumbara shalatu ${ }^{10}$ are having kashaya rasa and thus having vrana ropak, stambhaka and shothahara properties. Drug like nimb and jaati are having immune stimulant, anti-inflammatory and antimicrobial effect which helps in protection from invasion of microorganisms. 


\section{CONCLUSION}

Hence in this case we can conclude that bahirparimarjan chikitsa in the form of Udumbradi tail is highly effective in disintegration of pathogenesis of karnini yonivyapad (cervical erosion). No adverse effect or complications is produced with the use of this treatment. This treatment is safe economic, non-surgical, very effective and can be used for treatment of cervical erosion.

\section{ACKNOWLEDGEMENT}

Authors are thankful to C.M. Jain, H.O.D. Dept. of Prasuti-Stree Roga, National Institute of Ayurveda, Jaipur, Rajasthan, India and B. Pushaplatha, Lecturer, Dept. of Prasuti-Stree Roga, National Institute of Ayurveda, Jaipur, Rajasthan, India for their valuable guidance to publish this manuscript.

\section{REFERENCES}

1. Dutta DC. Text book of gynecology including contraception; Benign lesion of cervix; Chapter 18; Fifth Edition: Kolkata; New Central Book Agency (P) Ltd. 2008, Revised Reprint; 2009. p. 257

2. Dutta DC. Text book of gynecology including contraception; Benign lesion of cervix; Chapter 18; Fifth Edition: Kolkata; New Central Book Agency (P) Ltd. 2008, Revised Reprint; 2009. p. 257

3. Tiwari Premvati. Ayurvedia Prasutitantra Avam Striroga, Vol.II; Yonivyapad; Chapter 1; Second Edition. Chaukamba Orientalia Varanasi;2000, Reprint; 2005. p. 41
4. Charaka, Charaka Samhita, Chikitsa Sthan 30/27, Vol.2 Commented By Sastri Kashinath And Chaturvedi Gorakhanath, Published By Chaukhambha Bharti Academy, Varanasi, Reprint Year; 2003. p. 844

5. Susruta.Sushruta Samhita, Uttar tantra 38/28, Vol.2 Shastri Ambikadutta, Published Chaukhambha Sanskrit Sansthan Varanasi, Reprint; 2005. p. 163

6. Charaka, Charaka Samhita, Chikitsa Sthan 30/109, Vol.2 Commented By Sastri Kashinath And Chaturvedi Gorakhanath, Published By Chaukhambha Bharti Academy, Varanasi, Reprint Year; 2003. p. 857 PMid:14702957

7. Charaka, Charaka Samhita, Chikitsa Sthan 30/76, Vol.2 Commented By Sastri Kashinath And Chaturvedi Gorakhanath, Published By Chaukhambha Bharti Academy, Varanasi, Reprint Year; 2003. p. 851 PMid:14521221

8. Charaka, Charaka Samhita, Sutra Sthan 27/286, Vol.1 Commented By Sastri Kashinath And Chaturvedi Gorakhanath, Published By Chaukhambha Bharti Academy, Varanasi, Reprint Year; 2003. p. 556

9. Sharma PV. Dravyagunavigyana, Vol.2, Chaukhambha Bharti Academy, Varanasi.Reprint; 2005. p. 221

Cite this article as:

Chaurasia Ranju Kumari, Bhati Kuldeep Singh. Role of Udumbaradi tail in the management of vaginal discharge due to cervical erosion: A case report. Int. J. Res. Ayurveda Pharm. 2013;4(4):631-633 http://dx.doi. org/10.7897/2277-4343.04438 